one traces the development of radar, and in another the problems of drift and dispersal are considerod.

Migration apart, the phenomenon of starling roosts is described, and their dispersal is discussed. Species in which migration at present scems to be a minor phenomonon receive consideration and ccological examination, whilo changes in the habitat of certain thrushes aro traced. Before the concluding chapter are three in which owls, falcons and hawks, together with their connexion with pigeons, wild birds and keepers. are examined.

The book is not aimed particularly at tho specialist. General readers to whom I have lent my copy have found fascination among its chapters, while the amateur naturalist of many types will read it from eover to cover.

H. Dunnictiff

\section{DEVELOPMENT AND LEARNING}

\section{Education and Physical Growth}

Implications of tho Study of Children's Growth for Educational Thoory and Practico. By Dr. J. M. Tanner. Pp. 144. (London: University of London Press, Lld., 1961.) 12s. 6d. net.

A LTHOUGH the frequoney of educational theories $A$ bears some similarity to the number of educa. tionists and changes with bewildering rapidity, the numbor of substantiated facts on which the thoories aro based is still lamentably small. It was a hapoy thought, thornforo, of the Univorsity of Leeds Instituto of Education to invito a leading authority on human growth to prosont a series of lectures in which his work could bo related to presont-day educational theory and practice.

These lectures have boen brought togothor in a valuablo book which provides much useful information about the development of children. Tanner's own work on tho growth curves of physical characteristiss, such as hoight, weight, musclo and skelotal strueturo, is examines along with existing knowledge about the way in which growth gradients emerge. Even moro significant for educationists are his descriptions of critica! periods of growth in animals which, depending on tho stimulus (or lack of it) from the environmont at the right timo, may lead to the omergonce (or repression) of certain qualities or characteristics. If such eritical poriods wore confirmod in children, the need for educationists to bring out the appropriato onvironmental stimulus at the critical timo would become all too ovidont. Yet, as 'Tunnor demonstrates, the lack of substantive facts about the growth of ehildren enables him to provide few answors but many questions; the solution to these will only bo provided whon the amount of fundamental researeh on ehild growth is increasod considerat)ly.

'To ono pressing problem, however, cnough information is available to provido a solution which sooms clear and unquostionable. The difforont way in which difforent abilities emorge in young adolescents at difforing times indicatos that the raising of tho school-leaving ago for all children to sixteon yoars of age runs counter to all the demands and roquirements of somo of these children. To carry out such a doubt,ful policy is a striking example of how misgnided humanitarianism supported by tidy administration can fly in the face of all known facts. 'Tanner's book may well cause such zcalots to think again. It should be read not only by professional educationists but also by members of national and local education committees. The day may even come when such a work is made obligatory reading for all who have the chargo of young people in industry.

Kathlleen M. Hawkins

\section{PLACE-NAMES IN THE WEST RIDING OF YORKSHIRE}

The Place-Names of the West Riding of Yorkshire By A. H. Smith. Part 4: Barkston Ash, Skyrack and Ainsty Wapentakos. Pp. xii +262 . Part 5: Uppor and Lower Claro Wapentakes. Pp. xii +222 . Part 6: Last and West Staincliffo and Eweross Wapentakes. Pp. xii + 274. (English Placo-name Society, Volumes 33, 34 and 35.) (Cambridgo: At the University Pross, 1961.) 35s. net.; 6.50 dollars each volume.

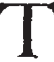

HE present throo volumes form the second instalmont of a total of oight concerned with the West Riding, and it is good to see thom follow so quickly on the oarlior three which woro reviewed in Nature $(191,208 ; 1961)$. Tho soventh volumo will be concornod with the interprotation of the matorial now completely assombled, and tho oighth will consist of a general index to the place-names of Yorkshire as a whole. The present three volumes cover the county to the north of the Aire. They follow the earlier threo volumes in including a large numbor of minor namos and field names. Street-namos of the largo settlements are also given space, and the whole constitutes a most impressive array of detailed evid. ence.

We must wait until Volume 7 for a comprehensive assessment of this mass of material. In the moantimo, anyone who turns over the pages of the prosent volumes is loft with at least two broad impressions. Ono is the intermingling of English and Scandinavian elements, not perhaps so frequently as in some other parts of northern England, but certainly very noticcably. Scandinavian clements occur not only in names of adjacont townships and in juxtaposition within tho same township but also sometimes eombinod within a singlo name; and there are also many examples of Scandinavianized forms of English names. A second impression is that of the large numbor of names that indicato the former prosence of wood. Wo must picture the West Riding as being vory largely covered by tracts of wood extending up tho valloys below the bleak moorlands which offorod pasture for shoop.

Our ixopressions of these distributions will como more clearly into focus when Volumo 7 is available. The implications of this gront harvest of evidence will then be made sloar in the form of analysos of the types of namos togother with notes on their distribu. tion, illustratod by maps. The interpretation of this matorial in the light of the wide variations in the geography of the county and in relation to the gonoral history of Fngland will constitute a major contribution, far transcending its philological importanes, that in itself may woll bo considerablo, for through the West Riding ran the boundary botwoon Mercians and Northumbrians. In tho meantime, we can but, salute the meticulous scholarship of tho prosont volumes, und congratulate tho Inglish Placo-Name Socioty on its continuing contributions to English scholarship.
H. C. Darby 